\title{
Database to standardize mouse phenotyping
}

Munich

A pilot study to systematically characterize 21 commonly used inbred - and thus genetically homogeneous - strains of mice has been launched by scientists in several US laboratories. The study is the first action of a project called the Mouse Phenotyping Initiative, which aims to create a publicly accessible database of the characteristics known as traits or phenotypes - of inbred mouse strains.

According to members of the initiative's steering group, chaired by Ken Paigen, director of the Jackson Laboratory in Bar Harbor, Maine, such a database is urgently needed by mouse geneticists, as there is currently a lack of information about the strains that are routinely used to model human diseases.

Paigen is the driving force behind the initiative, which will set up the database at the Jackson Laboratory, the world's leading supplier of inbred mouse strains. The laboratory already hosts the Mouse Genome Database, which is accessible to researchers throughout the world.

With the Human Genome Project nearing completion, scientists are becoming increasingly interested in investigating the functions of the genes that have been sequenced, and mice have become a classic genetic tool in this endeavour.

Scientists around the world are due to finish sequencing the mouse genome by 2005 . The speed of its completion was boosted by the creation earlier this month of the Mouse Genome Sequencing Network, funded by the US National Institutes of Health (NIH). The network involves ten collaborating laboratories which will share US\$21 million over the next six months.

In addition, there are already hundreds of relevant inbred strains and thousands of mutant strains, created either by 'knockout' technologies, which target particular genes for deletion, or by chemical mutagenesis.

Geneticists use inbred strains to analyse complex physiological or behavioural traits, such as a propensity to a particular type of cancer, or a taste for alcohol. They can start to pin down the genes that determine the trait by crossing a strain that strongly displays a particular trait with one that displays it weakly, or not at all, and working back from genomic information. A more precise understanding of the phenotypes of inbred strains will allow experimenters to select the most appropriate strains for cross-breeding.

The Mouse Phenotype Initiative's steering group, which has two European, one Japanese and six US members, has drawn up a list of inbred strains and phenotypes that it thinks should be included in the database. It recommends that 20 animals from each strain be analysed in two different laborato-

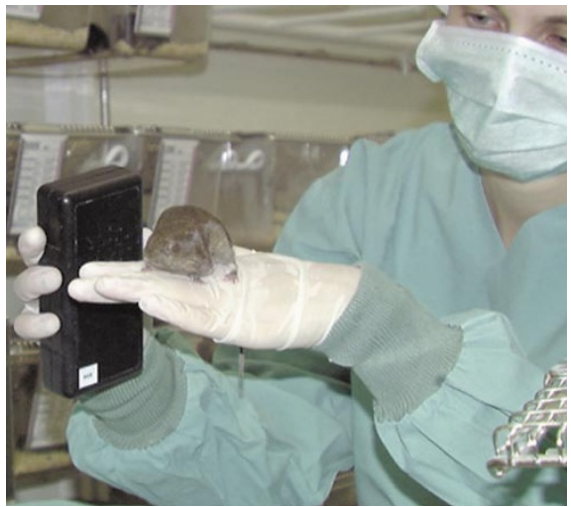

Hearing aid: a mouse is tested for hereditary deafness, giving clues to its genetic origins.

ries with expertise in a particular area, such as behaviour or clinical chemistry.

The steering group has suggested that data already published should not be included, because strains bred in different laboratories sometimes undergo 'genetic drift' and so can no longer be assumed to be identical to the reference strain from which they were derived. The Jackson Laboratory will provide all the mice that will be phenotyped for the database.

The pilot study, which will be conducted at the Howard Hughes Medical Institute at Northwestern University in Chicago, Baylor College of Medicine, and the Jackson Laboratory, will study three characteristics: circadian rhythms, haematology and the response to a high-fat, high-cholesterol diet.

Funding for the pilot study has come from donations from pharmaceutical companies. Rick Woychik, director of the ParkeDavis Laboratory for Molecular Genetics at Oakridge, California, one of the donors, says the database will be an "immensely powerful

tool" for industry, which needs optimal mouse models to identify genes involved in human diseases. But long-term financing has not yet been secured.

Major funding agencies, including the NIH, Britain's Medical Research Council and France's INSERM, will be asked by the initiative's steering committee to fund laboratories involved in phenotype assessment and database management. Pharmaceutical companies will also be approached.

If such funding is secured, later phases of the project will include up to 50 different strains of mice and all phenotypes for which there is interest in the research community.

"The Mouse Phenotype Initiative is important because we need to develop comprehensive, common and systematic phenotyping tests," says Steve Brown, director of the Mammalian Genetics Unit of Britain's Medical Research Council. "In particular, clinical vocabulary should be standardized to the mouse, since the mouse is used to model human disease."

But mouse pathologists are rare, he points out. This was recognized last year by the NIH, which is set to fund several mutagenesis centres. These will focus on recessive genetic traits, to complement the European focus on dominant traits, and will be grouped into two areas: behaviour and development.

Maja Bucan, a geneticist at the Center for Neurobiology and Behavior at the University of Pennsylvania, who runs a mouse mutagenesis programme screening for behavioural traits, says "we all went into mutagenesis studies without information about how phenotyping should be standardized, and now we have to go back and do it. This is exactly why [the Mouse Phenotype Initiative] is so important."

Alison Abbott

\section{Japan wins bid for top Unesco post}

\section{London}

Koichiro Matsuura, Japan's ambassador to France, is expected to be officially appointed next month as the new director-general of the United Nations Educational, Scientific and Cultural Organization (Unesco).

This follows his nomination last week by the UN agency's executive board, after Matsuura obtained 34 of the 58 votes in the third round of voting, a wide lead over his two closest rivals, Ghazi Algosaibi of Saudi Arabia and Ismail Serageldin of Egypt, a vice-president of the World Bank.

In an interview with Nature earlier this year, Matsuura promised that a more efficient bureaucracy and greater efforts to persuade the United States to rejoin the

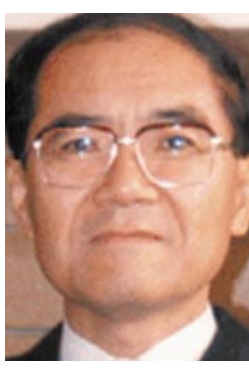

organization would be high among his priorities (see Nature 398, 554; 1999). "US reentry is very important," Matsuura said. "We cannot hope to have meaningful discussions without the United States as an Matsuura: seeking to active participant." foster consensus.

He also said that Japan was keen to bring its consensus-style approach to problem solving to international issues. He pointed, for example, to the conference of parties to the UN climate convention, held 
two years ago in Kyoto, at which Japan, together with the European Union, successfully steered a middle course between the positions of the United States and developing countries.

Matsuura's appointment is the result of an intense campaign by the Japanese government, which is keen to raise its profile in international affairs. He had the active support of physicist Akito Arima, formerly the president of the University of Tokyo, and until recently his country's minister of education and research. And the Japanese prime minister, Keizo Obuchi, an old schoolfriend, is said to have lobbied several European heads of state on Matsuura's behalf.

This campaign has led to speculation that Japan may have promised additional aid to some developing countries in return for their support for Matsuura's nomination. Matsuura has extensive experience of dealing with such countries, having been an architect of Japan's aid policies during the 1980s.

But he is said to have performed only moderately well in his interview with the executive board, and his appointment is widely seen as a vote for the Japanese government, rather than the ambassador personally. Japan is Unesco's largest donor country, and contributes 25 per cent of the organization's $\$ 544$ million annual budget. David Dickson and Peter Pockley

\section{US Congressman boycotts science meeting with China}

\section{San Diego}

The first in a planned decade-long series of meetings between US and Chinese scientific leaders was marred this week by the withdrawal of a powerful US Congressman, citing allegations of Chinese spying and illegal technology uses.

James Sensenbrenner (Republican, Wisconsin), chairman of the House Science Committee, cancelled his plans to attend the Sino-US Joint Science Policy Seminar as the delegation was leaving for the four-day meeting with representatives of the National Natural Sciences Foundation of China, due to open in Beijing last Sunday (24 October).

Sensenbrenner contacted Rita Colwell, the director of the National Science Foundation (NSF), the meeting's sponsor, asking her to cancel the delegation's trip because of continued Chinese provocations. "A seminar with senior officials from the White House and Congress could convey to the Chinese a business-as-usual attitude in our relationship on science and technology," Sensenbrenner said in a statement.

The Congressman was angered by the indictment earlier this month of the China National Aero-Technology Import and Export Corporation and the McDonnell
Douglas Corporation for the alleged illegal transfer of US defence technology to a Chinese missile factory.

$\mathrm{He}$ also quoted allegations of Chinese spying involving nuclear bomb secrets from the Los Alamos National Laboratory in New Mexico (see Nature 399, 395; 1999), and "mischaracterizations" by Chinese officials visiting Congress this month for the first time since the Tiananmen Square conflict.

But Colwell declined to call off the trip, saying in a statement that "I've consulted widely with colleagues within and without [President Bill Clinton's] administration, and there is unanimity that the seminar is not linked to Sensenbrenner's specific concerns".

Colwell said the event "reflects the principle of free circulation of scientists and our continuing commitment to an open discussion of issues of common scientific interest".

US participants at the seminar included representatives from the NSF, the National Institutes of Health, the National Academy of Engineering and several universities. The latter included Richard C. Atkinson, president of the University of California - ironically, the institution that manages the Los Alamos laboratory from which nuclear secrets are alleged to have been stolen. Rex Dalton

\section{European biologists unite to lobby for more money}

\section{Munich}

A group ofleading European molecular biologists is to launch a new initiative, called the European Life Sciences Forum (ELSF), to present a united view to politicians of the needs of the basic research community in Europe.

Frank Gannon, director of the Heidelberg-based European Molecular Biology Organization (EMBO), told the Munich Symposium on Cell Dynamics last week that the forum was necessary because of the fragmentation of the community's voice.

This fragmentation had weakened the impact of researchers on the European Union's fifth five-year Framework programme of research (FP5), which started this year, he said. "EMBO was one of very many life sciences organizations in Europe which individually advised the European Commission on how it should structure the programme, yet we saw no evidence of EMBO's input in the final design."

Given the "exponentially increasing" economic and social importance of life sciences, and the increasing demands of the biotech-

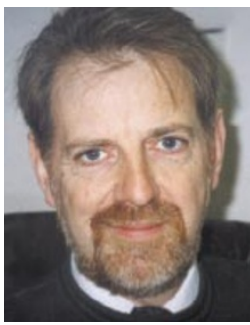

nology industry for advances in basic research, the life sciences need "a step up in funding, not incremental increases, as is currently the case in Europe," said Gannon.

One of the first tasks Gannon: life sciences of ELSF, whose manineed a single voice. festo will be published on the Internet, will be to establish dialogue with the European Commission and coordinate a single input into the sixth Framework programme on behalf of all European basic researchers in the life sciences when such discussions begin in the next two years.

Don Cleveland, a professor at the University of California at San Diego, told the Munich meeting that a recent commitment to doubling the budget of the National Institutes of Health by the US Congress had been largely due to a campaign by scientists in the US societies for cell biology, biochemistry and biophysics.

^๑ 1999 Macmillan Magazines Ltd
Ten years ago, said Cleveland, when the American Society of Cell Biology was still very small, it started to spend a significant proportion of its budget on paying a fulltime member of staff to "worry about public advocacy", as well as the services of a professional lobbyist in Washington. "At the time, some scientists said we were spending too much," he said. "But it paid off."

Other scientists at the meeting pointed to the success of Greenpeace's well-funded campaigns in Europe — such as that against genetically modified foods - which they said urgently needed to be matched by similarly competent campaigns by scientists.

Gannon pointed out that the task of lobbying is more complicated in Europe than in the United States. "We have to lobby in ten different languages and in twice as many political centres of power," he said.

But he said that scientists had themselves to blame for inadequate funding of life sciences in Europe "because we have never been able to come up with the simple sort of message that politicians can understand and convey to their constituents". Alison Abbott 